Review

\title{
Methylated DNA and microRNA in Body Fluids as Biomarkers for Cancer Detection
}

\author{
Yanning Ma, Xian Wang and Hongchuan Jin * \\ Laboratory of Cancer Biology, Department of Medical Oncology, Institute of Clinical Science, \\ Sir Runrun Shaw Hospital, Medical School of Zhejiang University, Hangzhou 310029, China; \\ E-Mails: mayanning0604@163.com (Y.M.); wangx118@yahoo.com (X.W.) \\ * Author to whom correspondence should be addressed: E-Mail: jinhc@zju.edu.cn; \\ Tel.: +86-571-8600-6366; Fax: +86-571-8600-6145.
}

Received: 11 March 2013; in revised form: 1 April 2013 / Accepted: 25 April 2013 / Published: 16 May 2013

\begin{abstract}
Epigenetic alterations including DNA methylation and microRNAs (miRNAs) play important roles in the initiation and progression of human cancers. As the extensively studied epigenetic changes in tumors, DNA methylation and miRNAs are the most potential epigenetic biomarkers for cancer diagnosis. After the identification of circulating cell-free nuclear acids, increasing evidence demonstrated great potential of cell-free epigenetic biomarkers in the blood or other body fluids for cancer detection.
\end{abstract}

Keywords: cancer; biomarker; DNA methylation; miRNAs

\section{Introduction}

Scientists have been engaged in dissecting the mechanism of carcinogenesis for decades and cancer was believed to be a genetic disease. Recently, epigenetics has attracted considerable attention and cancer was recognized as a disease of gene regulation. Although Conrad Waddington coined the word "epigenetics" (literally "over" or "upon" genetics) in the early 1940s to describe the discipline in biology that studies "the interactions of genes with their environment that bring the phenotype into being", it was currently referred more specifically to heritable changes in gene regulation that are not attributed to changes in DNA sequence [1].

Epigenetics is essential to maintain normal physiological processes to coordinate cell division and tissue-specifically differentiation in eukaryotic organisms. Epigenetic changes involve every aspect of 
gene regulation in response to environmental epimutagens such as the accessibility of chromosomal DNA to transcription factors and the translation efficiency of mRNA into proteins [2]. Epigenetic deregulations lead to a wide variety of pathological states such as cancers [3]. An explosion of data indicating epigenetic events associated with virtually every step of tumor development and progression, has led to the realization that epigenetic alterations cooperative with genetic abnormalities play important roles in the initiation and progression of human cancers [4,5]. Epigenetic alterations are believed to occur early in tumor development and may precede genetic changes, thus providing the possibilities of early diagnosis even prevention with the development of epigenetic biomarkers [6]. The emergence of advanced technologies to detect genome-wide epigenetic changes holds promise to advance our capacity to develop such biomarkers for detecting cancers at early stage [7].

DNA methylation, the addition of a methyl group to the cytosine pyrimidine ring, is important to maintain genome structure and regulate gene expression. Non-coding RNAs such as miRNAs could regulate gene expression by controlling mRNA stability and translation in addition to gene transcription. Recently, methylated DNA and miRNAs were found to be detected readily in the tissues even bloods, indicating that these epigenetic biomarkers could be the next generation of biomarkers for cancer detection. In this review, we will briefly overview recent advances in epigenetics and mainly discuss the development of DNA methylation and miRNAs as biomarkers for cancer detection.

\section{Methylated DNA as Biomarker}

\subsection{Overview of DNA Methylation}

The most extensively studied epigenetic modification in humans is DNA methylation. DNA methylation is a covalent modification that primarily occurs at Carbon-5 position of cytosine within CpG dinucleotides in mammals. It is mediated by a class of enzymes known as the DNMTs. Currently, several members of the DNMT family have been identified in mammals: DNMT1, DNMT1b, DNMT1o, DNMT1p, DNMT2, DNMT3a, DNMT3b and DNMT3L. DNMT 3A and DNMT3B are de novo enzymes and DNMT3L is an accessory enzyme for DNMT3a [8] while DNMT1 maintains the existing methylation pattern following DNA replication [9]. $\mathrm{CpG}$ dinucleotides scattered in the human genome are concentrated in short $\mathrm{CpG}$-rich DNA regions called $\mathrm{CpG}$ islands that locate in approximately $60 \%$ of human gene promoters and in regions of large repetitive sequences such as centromeres and retrotransposon elements [9-12]. While DNA methylation in repetitive sequences could be essential to prevent chromosomal instability and maintain chromosomal integrity, the dynamic methylation of $\mathrm{CpG}$ islands associates with the activity of gene expression during development and cell differentiation [13-17]. Methylated CpG islands hinder the binding of activating transcriptional factors to DNA sequences [18,19] or recruit inhibitory proteins such as histone deacetylases (HDACs) [20,21], thus leading to the silencing of genes. X chromosome inactivation and genomic imprinting are classical examples of such an epigenetic regulation [9]. During the initiation and progression of human cancers, many important tumor suppressor genes undergo silencing, thus affecting cellular signal pathways pivotal to carcinogenesis [22]. Recently, accumulating evidence suggests that epigenetic deregulation may precede the classical genetic changes such as mutations in 
tumor suppressors or oncogenes. Therefore, the detection of DNA methylation could reflect the early development of cancers.

\subsection{Methods to Detect DNA Methylation}

Given the landmark changes in human cancers, DNA methylation shows great promise as biomarkers for early cancer detection, prognosis and prediction $[17,18]$. With the advance of research on epigenomic alterations, the focus of recent studies has switched from methylation of a single locus in specific tumor suppressor promoters to a genome-wide methylation pattern [23-25]. Basically, all techniques developed for the detection of DNA methylation can be grouped into three classes according to the theoretical principles: sodium bisulfite conversion-dependent methods, restriction enzyme-dependent methods and affinity enrichment-dependent methods. As there is a wide array of technologies developed for DNA methylation detection, we only elucidate the representative ones as examples here.

The majority of methods are developed on the basis that sodium bisulfite deaminates unmethylated cytosines to uracil but leaves methylated cytosines unconverted [26]. After bisulfite conversion, there are a number of techniques available to determine $\mathrm{CpG}$ island methylation such as pyrosequencing, quantitative methylation-specific polymerase chain reaction (qMSP), methylation-sensitive single nucleotide primer extension (MS-SNuPE), bisulfate methylation profiling (BiMP), methylation-specific quantum dot fluorescence resonance energy transfer (MS-qFRET) and whole-genome shotgun bisulfite sequencing (WGSBS). Of the various techniques available, MSP is the most frequently used method to detect DNA methylation and qMSP seems to be superior in the detection of minute amounts of methylated DNA [27-30]. In this assay, primers are designed to overlap the CpG site of interest in the DNA template after sodium bisulfate treatment. It allows determining methylation states of particular sites sensitively and cost-effectively but with high false-positive rate since a small subset of the DNA copies have a substantially lower conversion rate [31]. In contrast to MSP that can only reflect the methylation status of single or few $\mathrm{CpG}$ sites within the primer sequence, Bisulfite Genomic Sequencing (BGS) can sequence multiple $\mathrm{CpG}$ sites within the amplicons when primers are designed to anneal with DNA sequence lacking $\mathrm{CpG}$ sites. When sodium bisulfate treatment is performed under appropriate conditions, the expected conversion efficiency of unmethylated cytosines can be up to $99 \%$ [32]. However, many factors such as contamination of proteins, strand separation efficiency and DNA quality contribute to the unsatisfactory conversion efficiency, thus limiting the wide application of bisulfite-conversion dependent methods clinically [31]. MS-qFRET combines the high specificity of MSP and the high sensitivity of the quantum dot FRET (QD-FRET) technology, showing the advantage of its potential application for high-throughput screening in multiplexing reactions [33]. An alternative approach for bisulfite treated DNA is matrix-assisted laser desorption/ionization time of flight (MALDI-TOF) mass spectrometry [34,35]. Although it is not a genome-wide scale technology, it can be reliably applied to pooled DNA samples to obtain group averages and can provide accurate results of multiple $\mathrm{CpG}$ dinucleotides for hundreds of gene loci.

Another class of techniques, restriction enzyme-dependent methods, utilizes the different ability of methylation sensitive/insensitive restriction enzymes to recognize and cleave given DNA sequences. The disadvantage of these methods is only a particular pattern of $\mathrm{CpG}$ sites can be analyzed. Many advanced techniques have been developed that couple enzymatic digestion to array-based hybridization. 
Differential methylation hybridization (DMH), MCA with microarray hybridization (MCAM), HpaII tiny fragment enrichment by ligation-mediated PCR (HELP) are examples of this class. Another method, methylation-specific multiplex ligation-dependent probe amplification (MS-MLPA), which intergrats the MLPA technique with methylated specific restriction enzymes, has proved to be a semiquantitative and convenient technique for evaluating the methylation status of multiple sequences simultaneously in tissue samples [36]. In a modified method termed Combined Bisulfite Restriction Analysis (COBRA), these restriction enzymes are also used to combine with bisulfate conversion to improve the analytical sensitivity and specificity.

In addition, methylated DNA can be enriched by antibodies specific to methylated cytosine or methyl-binding proteins. These approaches include methylated DNA immunoprecipitation (MeDIP) and methylated $\mathrm{CpG}$ island recovery assay (MIRA) [37]. Depending on the downstream platform used, enriched methylated DNA could be subject to whole-genome analysis by array-based hybridization or the next generation sequencing as well as gene-specific determination by PCR.

\subsection{Detection of DNA Methylation in the Blood and Other Body Fluids}

DNAs used for methylation analysis are usually extracted from tissues, thus limiting the clinical utility for early cancer diagnosis. In contrast, analysis of methylated DNA in the blood or other body fluids could reflect tumor burden in a non-invasive manner so as to be useful for cancer screening. Despite the first elucidation of cell-free nucleic acids (cf-NAs) in human bloods early in 1948 [38], it is not until 1990s that research on circulating cf-NAs starts to be prosperous. Moreover, epigenetic biomarkers were also detectable in other body fluids such as nipple aspirate [39,40], urine [41,42], sputum [43] and bronchoalveolar lavage [44].

The first analysis of plasma/sera DNA methylation was conducted in breast cancer [45]. After then, researches on plasma/serum and other body fluids have never stopped and demonstrated the potential of DNA methylation as markers for clinical application. Some important results in recent years are summarized in Tables 1 and 2. Many efforts have been dedicated to the discovery of novel methylated DNA for cancer detection. The methylation analysis of several genes rather than a single gene improves the clinical efficacy. For example, methylation of six genes including CYCD2, HIC1, PAX 5, RASSF1A, RB1 and SRBC can differentiate colorectal cancer patients from controls with sensitivity as $84 \%$ and specificity as $68 \%$ [46]. Similarly, methylation analysis of a gene panel containing APC, BIN1, BRCA1, CST6, GSTP1, P16, P21 and TIMP3 was developed to detect breast cancer with a sensitivity and specificity more than $90 \%$ [47]. Recent studies also compared or combined traditional clinical cancer markers with potential DNA methylation biomarkers. A genome-wide scale study with plasma and serum samples from 107 colorectal cancer patients and 98 individuals without colorectal cancer revealed that analysis of methylated THBD and C9orf50 outperformed carcinoembryonic antigen (CEA) measurement for early colorectal cancer detection [48]. Moreover, simultaneous measurements of both DNA methylation and carcinoembryonic antigen (CEA) resulted in increased sensitivity and specificity, even when either marker alone had low sensitivity [49]. 
Table 1. DNA methylation in plasma and serum as cancer markers.

\begin{tabular}{|c|c|c|c|c|c|c|}
\hline Markers & Source & $\begin{array}{l}\text { Sample } \\
\text { number }\end{array}$ & Sensitivity & Specitivity & Technology & Ref. \\
\hline \multicolumn{7}{|l|}{ Breast cancer } \\
\hline ESR1,14-3-3-r & Serum & 274 & $81 \%$ & $88 \%$ & qMSP & {$[50]$} \\
\hline SLC19A3 & Plasma & 78 & $90 \%$ & $85 \%$ & qMSP & [51] \\
\hline GSTP1,RARB, RASSF1, APC & Plasma & 169 & $62 \%$ & $87 \%$ & qMSP & [52] \\
\hline SOX17 & Plasma & 139 & $37 \%$ & $98 \%$ & MSP & {$[53]$} \\
\hline DKK3, ITIH5 & Serum & 243 & $40 \%$ & $93 \%$ & MSP & {$[54]$} \\
\hline RASSF1A,DKK3, ITIH5 & Serum & 243 & $67 \%$ & $69 \%$ & MSP & [5] \\
\hline $\begin{array}{l}\text { APC, BIN1, BMP6, BRCA1, } \\
\text { CST6, ESR-b, GSTP1, P16, P21 } \\
\text { and TIMP3 }\end{array}$ & Plasma & 126 & $>90 \%$ & $>90 \%$ & EpiTYPER & [47] \\
\hline \multicolumn{7}{|l|}{ Colorectal cancer } \\
\hline ALX4 & Serum & 82 & $83 \%$ & $70 \%$ & qMSP & {$[55]$} \\
\hline $\mathrm{CDH} 4$ & $\begin{array}{l}\text { Peripheral } \\
\text { Blood }\end{array}$ & 63 & $70 \%$ & $100 \%$ & MSP & {$[56]$} \\
\hline NGFR & Plasma & 312 & $51 \%$ & $84 \%$ & qMSP & {$[57]$} \\
\hline SEPT9 & Plasma & 312 & $69 \%$ & $86 \%$ & qMSP & {$[57]$} \\
\hline TMEFF2 & Plasma & 312 & $65 \%$ & $69 \%$ & qMSP & [57] \\
\hline RUNX3 & Serum & 75 & $68 \%$ & $89 \%$ & MSP & {$[58]$} \\
\hline SEPT9 & Plasma & 1510 & $77 \%$ & $91 \%$ & qMSP & [59] \\
\hline MGMT & plasma & 583 & $39 \%$ & $96 \%$ & MSP & [29] \\
\hline RAR $\beta 2$ & Plasma & 583 & $24 \%$ & $100 \%$ & MSP & [29] \\
\hline RASSF2A & Plasma & 583 & $58 \%$ & $100 \%$ & MSP & [29] \\
\hline Wif-1 & plasma & 583 & $74 \%$ & $98 \%$ & MSP & [29] \\
\hline \multicolumn{7}{|l|}{ Lung cancer(NSCLC) } \\
\hline SHOX2 & Plasma & 411 & $60 \%$ & $90 \%$ & qMSP & {$[60]$} \\
\hline $\begin{array}{l}\text { APC, RASSF1A, CDH13, KLK10 } \\
\text { and DLEC1 }\end{array}$ & Plasma & 160 & $83 \%$ & $70 \%$ & MSP & [61] \\
\hline DLEC1 & Plasma & 128 & $36 \%$ & $98 \%$ & MSP & {$[62]$} \\
\hline RAR $\beta 2$ & Plasma & 141 & $28 \%$ & $48 \%$ & MSP & [63] \\
\hline CDH1 & Serum & 106 & $62 \%$ & $70 \%$ & qMSP & [64] \\
\hline $\begin{array}{l}\text { APC, AIM1, CDH1, DCC, } \\
\text { MGMT, RASSF1A }\end{array}$ & Serum & 106 & $84 \%$ & $57 \%$ & qMSP & {$[64]$} \\
\hline CDH13 & Plasma & 99 & $33 \%$ & $83 \%$ & MSP & {$[65]$} \\
\hline \multicolumn{7}{|l|}{ Gastric cancer } \\
\hline KCNA4, CYP26B1 & Serum & 92 & $91 \%$ & $92 \%$ & MSP & [66] \\
\hline \multicolumn{7}{|l|}{ Hepatocellular carcinoma } \\
\hline APC, GSTP1, RASSF1A, SFRP1 & Plasma & 150 & $93 \%$ & $82 \%$ & MSRE-qPCR & [67] \\
\hline TFPI2 & Serum & 93 & $46 \%$ & $72 \%$ & MSP & [68] \\
\hline \multicolumn{7}{|l|}{ Head and neck squamous } \\
\hline CDH1, TIMP3, HIC1, PGP9.5 & Serum & 251 & 81 & 43 & qMSP & [69] \\
\hline
\end{tabular}


Table 1. Cont.

\begin{tabular}{|c|c|c|c|c|c|c|}
\hline Markers & Source & $\begin{array}{l}\text { Sample } \\
\text { number }\end{array}$ & Sensitivity & Specitivity & Technology & Ref. \\
\hline \multicolumn{7}{|l|}{ Ovarian cancer } \\
\hline $\begin{array}{l}\text { BRCA1, HIC1, PAX5, PGR, } \\
\text { THBS1 }\end{array}$ & Plasma & 66 & $85 \%$ & $61 \%$ & MethDet test & {$[70]$} \\
\hline RASSF1A, CALCA, EP300 & Plasma & 60 & $90 \%$ & $87 \%$ & MethDet test & [71] \\
\hline \multicolumn{7}{|l|}{ Pancreatic cancer } \\
\hline $\begin{array}{l}\text { CCND2, PLAU, SOCS1, THBS, } \\
\text { VHL }\end{array}$ & Plasma & 60 & $76 \%$ & $59 \%$ & MethDet test & {$[72]$} \\
\hline NPTX2 & Plasma & 169 & $80 \%$ & $76 \%$ & qMSP & [73] \\
\hline $\mathrm{p} 16$ & Plasma & 83 & $24 \%$ & $\mathrm{~N} / \mathrm{A}$ & MSP & [74] \\
\hline \multicolumn{7}{|l|}{ Bladder cancer } \\
\hline $\begin{array}{l}\text { TIMP3, APC, RARB, TIG1, } \\
\text { GSTP1, p14, p16, PTGS2, } \\
\text { RASSF1A }\end{array}$ & Serum & 148 & $62 \%$ & $89 \%$ & MSRE-qPCR & {$[75]$} \\
\hline APC, GSTP1, TIG1 & Serum & 90 & $80 \%$ & $93 \%$ & qMSP & [76] \\
\hline \multicolumn{7}{|l|}{ Prostate cancer } \\
\hline GSTP1, RASSF1, RARß2 & Serum & 123 & $63 \%$ & N/A & MSP & [28] \\
\hline GSTP1, MDR1 & Serum & 227 & $32 \%$ & $100 \%$ & qMSP & [77] \\
\hline GSTP1, TIG1, PTGS2, RPRM & Serum & 210 & $47 \%$ & $93 \%$ & qMSP & [78] \\
\hline
\end{tabular}

Sensitivity is defined as the percentage of confirmed cases of disease, in which methylation of a marker is found in serum or plasma; Specificity is defined as the percentage of controls without the disease that are lack of detectable methylation in serum or plasma; N/A: not available; qMSP: quantitative methylated-specific PCR; NSCLC: non-small cell lung cancer; MSRE-qPCR: methylation sensitive restriction enzyme-quantitative PCR.

Table 2. DNA methylation in other body fluids as cancer markers.

\begin{tabular}{|c|c|c|c|c|c|c|}
\hline Markers & Source & $\begin{array}{l}\text { Sample } \\
\text { number }\end{array}$ & Sensitivity & Specitivity & Technology & Ref. \\
\hline \multicolumn{7}{|l|}{ Lung cancer } \\
\hline $\begin{array}{l}\text { CDKN2A/p16, TERT, } \\
\text { WT1, RASSF1 }\end{array}$ & $\begin{array}{l}\text { Bronchial } \\
\text { washings }\end{array}$ & 248 & $82 \%$ & $91 \%$ & qMSP & {$[30]$} \\
\hline $\begin{array}{l}\text { DAPK, PAX5b, PAX5a, Dal1, } \\
\text { GATA5, SULF2, CXCL14 }\end{array}$ & Sputum & 130 & $75 \%$ & $68 \%$ & Nest qMSP & {$[79]$} \\
\hline \multicolumn{7}{|l|}{$\begin{array}{l}\text { Non small cell lung } \\
\text { cancer (NSCLC) }\end{array}$} \\
\hline CDH13 & Sputum & 190 & $27 \%$ & $75 \%$ & Nest MSP & [80] \\
\hline CDKN2A/p16 & Sputum & 190 & $40 \%$ & $73 \%$ & Nest MSP & [80] \\
\hline DAPK & Sputum & 190 & $43 \%$ & $67 \%$ & Nest MSP & {$[80]$} \\
\hline GATA4 & Sputum & 190 & $49 \%$ & $54 \%$ & Nest MSP & {$[80]$} \\
\hline IGFBP3 & Sputum & 190 & $25 \%$ & $54 \%$ & Nest MSP & [80] \\
\hline
\end{tabular}


Table 2. Cont.

\begin{tabular}{|c|c|c|c|c|c|c|}
\hline Markers & Source & $\begin{array}{l}\text { Sample } \\
\text { number }\end{array}$ & Sensitivity & Specitivity & Technology & Ref. \\
\hline \multicolumn{7}{|l|}{$\begin{array}{l}\text { Head and neck squamous cell } \\
\text { carcinoma (HNSCC) }\end{array}$} \\
\hline $\begin{array}{l}\text { MINT31, MGMT, } \\
\text { CCNA1, p16 }\end{array}$ & $\begin{array}{l}\text { Salivary } \\
\text { rinse }\end{array}$ & 391 & $35 \%$ & $90 \%$ & qMSP & [69] \\
\hline $\begin{array}{l}\text { DAPK, DCC, MINT-31, TIMP-3, } \\
\text { p16, MGMT, CCNA1 }\end{array}$ & Salivary & 61 & $54 \%$ & N/A & qMSP & [81] \\
\hline \multicolumn{7}{|l|}{ Prostate cancer } \\
\hline GSTP1 & Urine & 192 & $81 \%$ & $94 \%$ & qMSP & [82] \\
\hline RASSF2 & Urine & 192 & $59 \%$ & $63 \%$ & qMSP & [82] \\
\hline HIST1H4K & Urine & 192 & $92 \%$ & $86 \%$ & qMSP & [82] \\
\hline TFAP2E & Urine & 192 & $100 \%$ & $18 \%$ & qMSP & [82] \\
\hline $\begin{array}{l}\text { GSTP1, RASSF1A, } \\
\text { ECDH1, APC, DAPK, MGMT, } \\
\text { p14, p16 }\end{array}$ & $\begin{array}{l}\text { Urine post } \\
\text { massage }\end{array}$ & 95 & $93 \%$ & N/A & MSP & [83] \\
\hline PCDH17,TCF21 & Urine & 77 & $26 \%$ & $100 \%$ & qMSP & [84] \\
\hline \multicolumn{7}{|l|}{ Colorectal cancer } \\
\hline TFPI2 & Stool & 197 & $76 \%-89 \%$ & $79 \%-93 \%$ & qMSP & [85] \\
\hline GATA4 & Stool & 58 & $71 \%$ & $93 \%$ & MSP & [86] \\
\hline NDRG4 & Stool & 58 & $77 \%$ & $100 \%$ & qMSP & [87] \\
\hline Vimentin exon-1 & Stool & 292 & $46 \%$ & $90 \%$ & MSP & [88] \\
\hline \multicolumn{7}{|l|}{ Bladder cancer } \\
\hline PCDH17,TCF21 & Urine & 98 & $60 \%$ & $100 \%$ & qMSP & [84] \\
\hline GDF15 & Urine & 71 & $47 \%$ & $100 \%$ & qMSP & [89] \\
\hline HSPA2 & Urine & 71 & $59 \%$ & $100 \%$ & qMSP & [89] \\
\hline TMEFF2 & Urine & 71 & $63 \%$ & $100 \%$ & qMSP & [89] \\
\hline VIM & Urine & 71 & $78 \%$ & $100 \%$ & qMSP & [89] \\
\hline $\begin{array}{l}\text { VIM, TMEFF2, } \\
\text { GDF15, HSPA2 }\end{array}$ & Urine & 71 & $94 \%$ & $100 \%$ & qMSP & [89] \\
\hline $\begin{array}{l}\text { VAX1, KCNV1, } \\
\text { TAL1, PPOX1, CFTR }\end{array}$ & urine & 212 & $86 \%$ & $87 \%$ & MSP & [90] \\
\hline $\begin{array}{l}\text { ZNF154, POU4F2, } \\
\text { HOXA9, EOMES }\end{array}$ & Urine & 174 & $84 \%$ & $96 \%$ & MSP & [91] \\
\hline $\begin{array}{l}\text { SALL3, CFTR, ABCC6, HPR1, } \\
\text { RASSF1A, MT1A, RUNX3, } \\
\text { ITGA4, BCL2, ALX4, MYOD1, } \\
\text { DRM, CDH13, BMP3B, CCNA1, } \\
\text { RPRM, MINT1, BRCA1 }\end{array}$ & $\begin{array}{c}\text { urine } \\
\text { sediments }\end{array}$ & 168 & $92 \%$ & $87 \%$ & MSP & [92] \\
\hline \multicolumn{7}{|l|}{ Renal cell cancer } \\
\hline PCDH17, TCF21 & Urine & 98 & $32 \%$ & $100 \%$ & qMSP & [84] \\
\hline
\end{tabular}

Sensitivity is defined as the percentage of confirmed cases of disease, in which methylation of a marker is found in serum or plasma; Specificity is defined as the percentage of controls without the disease that are lack of detectable methylation in serum or plasma; N/A: not available. 
During clinical validation, parameters such as AUC (area under ROC curve) are common indicators used for evaluation of efficiency. Moreover, the sample size used in different studies affects the significance of the results. However, most of the proposed biomarkers lack convincing ROC analysis mainly due to limited number of cases enrolled in the study. In addition, most studies have only included a small number of healthy control subjects so that the normal patterns of DNA methylation are only poorly characterized. Therefore, most of methylated DNA biomarkers need to be validated by large-scale clinical trials, ideally prospectively, to finalize the convincing specificity and sensitivity. Interestingly, recent studies reported some methylation markers could be detected as positive even in patients with benign diseases [93] or heavy smokers [94]. These findings could account for the relatively unsatisfactory specificity $(<90 \%)$ of the potential biomarkers [52,57]. More fundamental studies are warranted to design further large-scale clinical trials for biomarker validations.

The first commercial DNA methylation test for the diagnosis of early colorectal cancer (CRC) and endometriosis is the detection of SEPT9 methylation. In a prospective trial with over 7900 average-risk screening guideline-eligible asymptomatic subjects, the first generation of SEPT9 test detected up to $48.2 \%$ of the cancer cases with the specificity as $91.5 \%$ [59]. However, the low sensitivity (11.2\%) for advanced adenomas hinders its clinical utility for cancer screening [59]. Other biomarkers being licensed includes methylated SHOX2 for lung cancer (Epi, proLung, Epigenomics AG) and methylated PITX2 for prostate cancer.

\subsection{Standardization of Methylation Analysis}

As no methods mentioned above are absolutely superior to others considering important assay parameters including high analytical sensitivity and specificity, accuracy, robustness, reproducibility, low risk of sample contamination, studies show different results with various analysis methods. The absence of standard methods affects the credibility of DNA methyaltion as valuable biomarkers for cancer detection. For example, GSTP1 methylation ranges from $21.4 \%$ to $73 \%$ in urine $[41,95,96]$ and from $36.2 \%$ to $72 \%[95,97]$ in plasma even with the same technique. The most important variant could be the different conditions in which urine or plasma/serum specimens are collected. Another key problem is the efficiency of DNA extraction and quantification of DNA after the standardization of sampling procedures such as collection and storage. Therefore, DNA methylation detection must be standardized to warrant the efficient development of DNA methylation as biomarkers for cancer [98]. Guidelines including universal individual laboratory protocols should be encouraged for the standardization of methylated DNA analysis.

\section{MiRNAs as Biomarkers}

\subsection{Overview of miRNAs}

MiRNAs are a class of small non-coding RNAs sequences of about 19-24 nucleotides that regulate targeted mRNAs post-transcriptionally to control gene expressions [99]. Precursor miRNAs with hairpin structures are generated from primary transcripts via processing of RNase II Drosha, exported from the nucleus to the cytoplasm in an Exportin-5-dependent manner. Eventually, they are cleaved by Dicer ribonucleases to form the functional mature miRNAs. Mature miRNAs are essential for 
silencing of gene expression by forming RNA-induced silencing complexes (RISC) to inhibit translation or promote mRNA degradation depending on the degree of their homology to the target sequences [100]. The first miRNAs, lin-4, was discovered in 1993 [101] and up to now, there are 2042 mature human miRNA sequences listed in the miRNA registry (Sanger miRBase, release19; Manchester, UK, 2012).

miRNAs have crucial functions in controlling the expressions of genes involved in virtually all biologic processes such as differentiation, proliferation, cell death, cell-cycle control, metabolism, haematopoiesis and aging [102-105]. Due to genetic and epigenetic changes including deletions or amplification of miRNA genes, epigenetic silencing or inhibition of processing, altered miRNA expression has been reported in various cancers [106,107]. For example, a five-miRNA signature for the prediction of treatment outcome of NSCLC was found in a cohort of 112 samples [108]. In another large sample retrospective analysis, five miRNAs were proved to have prognostic value for patients with nasopharyngeal carcinoma [109]. Recently, a mouse model has been used to identify serum microRNAs (miRNAs) as non-invasive biomarkers for diffuse-type gastric cancer early diagnosis [110]. While most miRNAs are generally downregulated in cancers, a few miRNAs, referred to as oncomiRNAs show elevated expression levels. This phenomenon indicated the potential role of these miRNAs as markers for early detection of cancer occurrence or recurrence in addition to the prediction of prognosis or response to various treatments [111].

\subsection{Methods to Detect miRNAs}

The main methods to detect miRNAs include quantitative RT-PCR (qRT-PCR), deep sequencing, microarray, in situ hybridization (ISH), enzymatic luminescence miRNA assay. Currently, qRT-PCR is the most commonly used for miRNA detection which can quantify the miRNAome from minute quantities of individual patient material [112]. Prior to the real time quantitative PCR, miRNAs are reversely transcribed to cDNA using a common RT primer or a pool of stem-loop RT primers specific for each miRNA [113].

A consensus protocol for analyzing miRNAs using qRT-PCR is emerging [114]. As miRNAs are single stranded, techniques that amplify these molecules usually use one unique and one universal primer, which provides less specificity than methods that use two unique primers [115]. The other problem is the normalization of miRNA expression. An ideal solution would be the identification of appropriate internal reference miRNA gene. However, there is currently no consensus on suitable small RNA reference genes [114]. MiR-16 or the small nucleolar RNA RNU62 and SNORD43 are frequently used as reference genes, but recent studies suggested that miR-16 is highly expressed in erythrocytes and its level in the blood can be affected significantly by the hemolysis [55-59]. Besides, RNU62 is less representative as it is not synthesized by the same polymerases that synthesize precursor miRNAs. An alternative normalization method is to establish mean expression levels of all tested miRNAs to reduce the technical variation in the miRNA isolation [116]. Further researches are needed for the uniformed standard to allow better comparisons and validations of miRNA biomarkers in the blood.

Isolation of miRNAs from serum and plasma is relatively straightforward. Exosome isolation can improve miRNA extraction from the circulation as the majority of miRNAs detectable in serum are 
contained in exosomes [117]. In addition, as some miRNAs are highly expressed in blood cells, the level of plasma miRNA biomarkers can be altered significantly by the various extents of hemolysis [118]. Detecting levels of free hemoglobin and certain miRNAs such as miR-15b and miR-16 may be necessary to determine whether a blood sample is suitable for further miRNA quantitation $[119,120]$. The standardization of sample processing and normalization of miRNAs analysis methodology is one of the most urgent requirements for preclinical screening and validation so as to facilitate the development of miRNA as biomarkers for clinical application.

\subsection{Detection of miRNA in Bloods and Other Body Fluids}

Specimens of solid cancer for miRNA detection are obtained either by biopsy or surgery. After the identification of circulating nuclear acids, researchers tried to detect circulating miRNAs in body fluids such as serum and plasma. Although the underlying mechanisms remain poorly understood, miRNAs in plasma or sera seem to be in a remarkably stable form that is resistant to RNase digestion even under harsh conditions including boiling, low/high $\mathrm{pH}$, extended storage time, and freeze-thaw cycles [121]. Hence, the levels of miRNAs in serum are stable, reproducible, and consistent among individuals of the same species even for several years [122]. In 2008, Lawrie, C.H. et al. described the presence of miRNAs in serum of cancer patients for the first time and found the association of miR21 with relapse-free survival of patients with diffuse large B cell lymphoma [123]. Blood-based miRNA expression profiles have since been shown to be potential biomarkers in cancer diagnosis and prognosis (Table 3). For example, serum level of miRNA-141 level was increased in the patients with prostate cancer and was able to detect prostate cancer with $100 \%$ specificity and $60 \%$ sensitivity [124]. In addition, miR-141 level in the blood was demonstrated to have a high correlation with other classical biomarkers particularly PSA [125].

Table 3. Circulating miRNAs as cancer biomarkers.

\begin{tabular}{cccc}
\hline Disease & Expression level & Markers & Ref. \\
\hline Breast cancer & Up-regulated & miR-155 & {$[126]$} \\
& & miR-195 & {$[127]$} \\
& miR-10b, miR -34a & {$[128]$} \\
& let7a, miR-195 & {$[129]$} \\
Colorectal cancer & Up-regulated & miR-29a, miR-21 & {$[130]$} \\
& & miR-17-3p,miR-92 & {$[131]$} \\
& & miR-29a, miR-92a & {$[132]$} \\
& & miR-221 & {$[133]$} \\
& & miR-29a & {$[134]$} \\
& & miR-141 & {$[135]$} \\
& & miR-34a & {$[136]$} \\
\hline
\end{tabular}


Table 3. Cont.

\begin{tabular}{|c|c|c|c|}
\hline Disease & Expression level & Markers & Ref. \\
\hline \multirow[t]{9}{*}{ Gastric cancer } & Up-regulated & miR-17-5p, miR-21, miR-106a, miR-106b & [138] \\
\hline & & miR-106a, miR-17 & [139] \\
\hline & & miR-378 & [140] \\
\hline & & miR-196a & [141] \\
\hline & & miR-200c & [142] \\
\hline & & miR-17-5p,miR-20a & [143] \\
\hline & & miR-21 & [144] \\
\hline & Down-regulated & let7a & [138] \\
\hline & & $\operatorname{miR}-195-5 p$ & [145] \\
\hline \multirow{6}{*}{$\begin{array}{l}\text { Non-small cell } \\
\text { lung carcinoma } \\
\quad(\text { NSCLC) }\end{array}$} & Up-regulated & miR-25,miR-223 & [121] \\
\hline & & $\begin{array}{l}\text { miR-17-3p, miR-21, miR-106a, miR-146, } \\
\text { miR-155, miR-191, miR-192, miR-203, } \\
\text { miR-205, miR-210,miR-212, miR-214 }\end{array}$ & [146] \\
\hline & & miR-1, miR-30d,miR-486, miR-499 & [147] \\
\hline & & $\operatorname{miR}-29 c$ & [148] \\
\hline & & miR-21, miR-205, miR-30d, miR-24 & [149] \\
\hline & Down-regulated & $\begin{array}{c}\text { miR-146b, miR-221, let-7a, miR-155, } \\
\text { miR-17-5p, miR-27a, miR-106a }\end{array}$ & [148] \\
\hline \multirow[t]{4}{*}{ Pancreatic cancer } & Up-regulated & miR-21, miR-155, miR-196a & [150] \\
\hline & & miR-210 & [151] \\
\hline & & miR-200a,miR-200b & [152] \\
\hline & & miR-18a & [153] \\
\hline \multirow{6}{*}{$\begin{array}{c}\text { Hepatocellular } \\
\text { carcinoma (HCC) }\end{array}$} & Up-regulated & miR-500 & [154] \\
\hline & & $\operatorname{miR}-375$ & [155] \\
\hline & & miR-122 & [156] \\
\hline & & miR-15b, miR-21, miR-130b, miR-183 & [157] \\
\hline & & let-7a, let-7f, miR-98 & [158] \\
\hline & & miR-21, miR-122, miR-223 & [159] \\
\hline $\begin{array}{l}\text { Head and } \\
\text { neck squamous } \\
\text { cell carcinoma } \\
\text { (HNSCC) } \\
\end{array}$ & Up-regulated & miR-21, miR-26b & [160] \\
\hline \multirow{3}{*}{$\begin{array}{l}\text { Oral squamous } \\
\text { cell carcinoma } \\
\quad(\text { OSCC })\end{array}$} & Up-regulated & $\operatorname{miR}-184$ & [161] \\
\hline & & miR-31,miR-21 & [162] \\
\hline & & miR-24 & [163] \\
\hline $\begin{array}{l}\text { Diffuse large B-cell } \\
\text { lymphoma } \\
\text { (DLBCL) }\end{array}$ & Up-regulated & miR-21,miR-155, miR-210 & {$[123]$} \\
\hline
\end{tabular}


Table 3. Cont.

\begin{tabular}{|c|c|c|c|}
\hline Disease & Expression level & Markers & Ref. \\
\hline $\begin{array}{c}\text { Acute } \\
\text { myeloid/leukemia } \\
\text { (AML), Acute } \\
\text { lymphoblastic } \\
\text { leukemia (ALL) }\end{array}$ & Up-regulated & let-7b, miR-523 & [164] \\
\hline Multiple myeloma & $\begin{array}{c}\text { Up-regulated } \\
\text { Down-regulated }\end{array}$ & $\begin{array}{c}\text { miR-720 } \\
\text { miR-1308 } \\
\end{array}$ & [165] \\
\hline \multirow[t]{5}{*}{ Prostate cancer } & Up-regulated & $\begin{array}{c}\text { miR-141, miR-200b } \\
\text { miR-16, miR-34b, miR-92a, miR-92b, } \\
\text { miR-103, miR-107, miR-197, miR-328, } \\
\text { miR-485-3p, miR-486-5p, miR-574-3p, } \\
\text { miR-636, miR-640,miR-766, miR-885-5p }\end{array}$ & $\begin{array}{l}{[124]} \\
{[166]}\end{array}$ \\
\hline & & $\operatorname{miR}-221$ & [167] \\
\hline & & miR-21, miR-221 & [168] \\
\hline & & $\begin{array}{c}\text { miR-93, miR-106a, miR-874, miR-1207-5p, } \\
\text { miR-1274a }\end{array}$ & [169] \\
\hline & Down-regulated & $\begin{array}{c}\text { miR-145, miR-155 } \\
\text { miR-24, miR-26b, miR-30c, miR-223 }\end{array}$ & $\begin{array}{l}{[129]} \\
{[169]}\end{array}$ \\
\hline \multirow[t]{2}{*}{ Ovarian cancer } & Up-regulated & $\begin{array}{l}\text { miR-21, miR-92, miR-93, miR-126, miR-29a } \\
\text { miR-21, miR-141, miR-200a, miR-200c, } \\
\text { miR-200b, miR-203, miR-205, miR-214 }\end{array}$ & $\begin{array}{l}{[170]} \\
{[171]}\end{array}$ \\
\hline & Down-regulated & $\operatorname{miR}-155$, miR- $127, \operatorname{miR} 99 \mathrm{~b}$ & [170] \\
\hline $\begin{array}{l}\text { Serous epithelial } \\
\text { ovarian cancer } \\
\text { (SEOC) } \\
\end{array}$ & Up-regulated & miR200a, miR200b, miR200c & {$[172]$} \\
\hline Glioblastoma & Up-regulated & miR-21 & [173] \\
\hline
\end{tabular}

MiRNAs have also been detected in other body fluids such as urine, tears, breast milk, bronchial lavage as well as pleural, peritoneal, and cerebrospinal fluids [174,175]. For example, increased levels of miRNAs in the urine often indicate the occurrence of urogynaecological cancers mainly bladder cancers and prostate cancers [176]. Similarly, miRNAs such as miR-205 was detectable in the sputum of patients with aerodigestive cancers like lung cancer [177]. In contrast, some miRNAs are downregulated in body fluids of cancer patients although the detailed mechanism remains unknown. For example, the levels of miR-125a and miR-200a were significantly lower in saliva of patients with oral squamous-cell carcinoma (OSCC) [178]. In pleural effusion from patients with lung cancer, the level of miR-198 was also decreased. When combined with the detection of CEA and CYFRA 21-1, miR-198 quantification even improved the sensitivity and specificity for the diagnosis of lung cancer [179].

\section{Conclusions and Perspectives}

In recent decades, the role of epigenetic alterations in carcinogenesis has received greater attention more than ever before. After elucidating the fundamental role of epigenetic changes in human carcinogenesis, considerable efforts have been devoted to the development of epigenetic biomarkers 
for cancer detection or monitoring and prognosis prediction [7,180]. Presence of cell-free methylated-DNA and miRNAs in blood opened up new perspectives in the development of cancer biomarkers for early cancer detection in a non-invasive manner. Encouraging results have been obtained using advanced techniques with high sensitivity and specificity. Undoubtedly, the diagnostic value of epigenetic molecules in panels or in combination with the conventional clinical biomarkers could be superior to individual markers $[46,47,49]$. In addition, it is urgent to standardize the methodologies including sample storage and DNA or miRNA extraction to translate the quantitation of circulating epigenetic biomarkers into a clinical routine for cancer diagnosis and prognosis predication $[181,182]$.

\section{Acknowledgments}

This work was supported by Program for Innovative Research Team in Zhejiang Province (No. 2010R50046) and Department of Health in Zhejiang Province to H.J. (No. N20100555; 20120542).

\section{Conflict of Interest}

The authors declare no conflict of interest.

\section{References}

1. Berger, S.L.; Kouzarides, T.; Shiekhattar, R.; Shilatifard, A. An operational definition of epigenetics. Genes Dev. 2009, 23, 781-783.

2. Holliday, R. Epigenetics: A historical overview. Epigenetics 2006, 1, 76-80.

3. Egger, G.; Liang, G.; Aparicio, A.; Jones, P.A. Epigenetics in human disease and prospects for epigenetic therapy. Nature 2004, 429, 457-463.

4. Baylin, S.B.; Herman, J.G. DNA hypermethylation in tumorigenesis: Epigenetics joins genetics. Trends Genet. 2000, 16, 168-174.

5. Jones, P.A.; Baylin, S.B. The fundamental role of epigenetic events in cancer. Nat. Rev. Genet. 2002, 3, 415-428.

6. Belinsky, S.A. Gene-promoter hypermethylation as a biomarker in lung cancer. Nat. Rev. Cancer 2004, 4, 707-717.

7. Deng, D.; Liu, Z.; Du, Y. Epigenetic alterations as cancer diagnostic, prognostic, and predictive biomarkers. Adv. Genet. 2010, 71, 125-176.

8. Jia, D.; Jurkowska, R.Z.; Zhang, X.; Jeltsch, A.; Cheng, X. Structure of Dnmt3a bound to Dnmt3L suggests a model for de novo DNA methylation. Nature 2007, 449, 248-251.

9. Bird, A. DNA methylation patterns and epigenetic memory. Genes Dev. 2002, 16, 6-21.

10. Takai, D.; Jones, P.A. Comprehensive analysis of CpG islands in human chromosomes 21 and 22. Proc. Natl. Acad. Sci. USA 2002, 99, 3740-3745.

11. Van Vlodrop, I.J.H.; Niessen, H.E.C.; Derks, S.; Baldewijns, M.M.L.L.; van Criekinge, W.; Herman, J.G.; van Engeland, M. Analysis of promoter CpG island hypermethylation in cancer: Location, location, location! Clin. Cancer Res. 2011, 17, 4225-4231.

12. Rodriguez-Paredes, M.; Esteller, M. Cancer epigenetics reaches mainstream oncology. Nat. Med. 2011, 17, 330-339. 
13. Walsh, C.P.; Chaillet, J.R.; Bestor, T.H. Transcription of IAP endogenous retroviruses is constrained by cytosine methylation. Nat. Genet. 1998, 20, 116-117.

14. Gaudet, F.; Hodgson, J.G.; Eden, A.; Jackson-Grusby, L.; Dausman, J.; Gray, J.W.; Leonhardt, H.; Jaenisch, R. Induction of tumors in mice by genomic hypomethylation. Science 2003, 300, 489-492.

15. Esteller, M.; Almouzni, G. How epigenetics integrates nuclear functions. EMBO Rep. 2005, 6, 624-628.

16. Wang, Y.; Leung, F.C.C. An evaluation of new criteria for $\mathrm{CpG}$ islands in the human genome as gene markers. Bioinformatics 2004, 20, 1170-1177.

17. Suzuki, M.M.; Bird, A. DNA methylation landscapes: Provocative insights from epigenomics. Nat. Rev. Genet. 2008, 9, 465-476.

18. Prendergast, G.C.; Ziff, E.B. Methylation-sensitive sequence-specific DNA binding by the c-Myc basic region. Science 1991, 251, 186-189.

19. Watt, F.; Molloy, P.L. Cytosine methylation prevents binding to DNA of a HeLa cell transcription factor required for optimal expression of the adenovirus major late promoter. Genes Dev. 1988, 2, 1136-1143.

20. Nan, X.; Ng, H.H.; Johnson, C.A.; Laherty, C.D.; Turner, B.M.; Eisenman, R.N.; Bird, A. Transcriptional repression by the methyl-CpG-binding protein $\mathrm{MeCP} 2$ involves a histone deacetylase complex. Nature 1998, 393, 386-389.

21. Jones, P.L.; Veenstra, G.J.; Wade, P.A.; Vermaak, D.; Kass, S.U.; Landsberger, N.; Strouboulis, J.; Wolffe, A.P. Methylated DNA and MeCP2 recruit histone deacetylase to repress transcription. Nat. Genet. 1998, 19, 187-191.

22. Esteller, M. Epigenetics in cancer. N. Engl. J. Med. 2008, 358, 1148-1159.

23. Hernandez-Vargas, H.; Lambert, M.P.; Le Calvez-Kelm, F.; Gouysse, G.; McKay-Chopin, S.; Tavtigian, S.V.; Scoazec, J.Y.; Herceg, Z. Hepatocellular carcinoma displays distinct DNA methylation signatures with potential as clinical predictors. PLoS One 2010, 5, e9749.

24. Martinez, R.; Martin-Subero, J.I.; Rohde, V.; Kirsch, M.; Alaminos, M.; Fernandez, A.F.; Ropero, S.; Schackert, G.; Esteller, M. A microarray-based DNA methylation study of glioblastoma multiforme. Epigenetics 2009, 4, 255-264.

25. Rauch, T.A.; Zhong, X.; Wu, X.; Wang, M.; Kernstine, K.H.; Wang, Z.; Riggs, A.D.; Pfeifer, G.P. High-resolution mapping of DNA hypermethylation and hypomethylation in lung cancer. Proc. Natl. Acad. Sci. USA 2008, 105, 252-257.

26. Clark, S.J.; Harrison, J.; Paul, C.L.; Frommer, M. High sensitivity mapping of methylated cytosines. Nucleic Acids Res. 1994, 22, 2990-2997.

27. Gobel, G.; Auer, D.; Gaugg, I.; Schneitter, A.; Lesche, R.; Muller-Holzner, E.; Marth, C.; Daxenbichler, G. Prognostic significance of methylated RASSF1A and PITX2 genes in bloodand bone marrow plasma of breast cancer patients. Breast Cancer Res. Treat. 2011, 130, 109-117.

28. Sunami, E.; Shinozaki, M.; Higano, C.S.; Wollman, R.; Dorff, T.B.; Tucker, S.J.; Martinez, S.R.; Mizuno, R.; Singer, F.R.; Hoon, D.S. Multimarker circulating DNA assay for assessing blood of prostate cancer patients. Clin. Chem. 2009, 55, 559-567.

29. Lee, B.B.; Lee, E.J.; Jung, E.H.; Chun, H.K.; Chang, D.K.; Song, S.Y.; Park, J.; Kim, D.H. Aberrant methylation of APC, MGMT, RASSF2A, and Wif-1 genes in plasma as a biomarker for early detection of colorectal cancer. Clin. Cancer Res. 2009, 15, 6185-6191. 
30. Nikolaidis, G.; Raji, O.Y.; Markopoulou, S.; Gosney, J.R.; Bryan, J.; Warburton, C.; Walshaw, M.; Sheard, J.; Field, J.K.; Liloglou, T. DNA methylation biomarkers offer improved diagnostic efficiency in lung cancer. Cancer Res. 2012, 72, 5692-5701.

31. Warnecke, P.M.; Stirzaker, C.; Song, J.; Grunau, C.; Melki, J.R.; Clark, S.J. Identification and resolution of artifacts in bisulfite sequencing. Methods 2002, 27, 101-107.

32. Taylor, K.H.; Kramer, R.S.; Davis, J.W.; Guo, J.; Duff, D.J.; Xu, D.; Caldwell, C.W.; Shi, H. Ultradeep bisulfite sequencing analysis of DNA methylation patterns in multiple gene promoters by 454 sequencing. Cancer Res. 2007, 67, 8511-8518.

33. Bailey, V.J.; Easwaran, H.; Zhang, Y.; Griffiths, E.; Belinsky, S.A.; Herman, J.G.; Baylin, S.B.; Carraway, H.E.; Wang, T.H. MS-qFRET: A quantum dot-based method for analysis of DNA methylation. Genome Res. 2009, 19, 1455-1461.

34. Ehrich, M.; Turner, J.; Gibbs, P.; Lipton, L.; Giovanneti, M.; Cantor, C.; van den Boom, D. Cytosine methylation profiling of cancer cell lines. Proc. Natl. Acad. Sci. USA 2008, 105, 4844-4849.

35. Ehrich, M.; Nelson, M.R.; Stanssens, P.; Zabeau, M.; Liloglou, T.; Xinarianos, G.; Cantor, C.R.; Field, J.K.; van den Boom, D. Quantitative high-throughput analysis of DNA methylation patterns by base-specific cleavage and mass spectrometry. Proc. Natl. Acad. Sci. USA 2005, 102, 15785-15790.

36. Jeuken, J.W.; Cornelissen, S.J.; Vriezen, M.; Dekkers, M.M.; Errami, A.; Sijben, A.; Boots-Sprenger, S.H.; Wesseling, P. MS-MLPA: An attractive alternative laboratory assay for robust, reliable, and semiquantitative detection of MGMT promoter hypermethylation in gliomas. Lab. Invest. 2007, 87, 1055-1065.

37. Weber, M.; Davies, J.J.; Wittig, D.; Oakeley, E.J.; Haase, M.; Lam, W.L.; Schubeler, D. Chromosome-wide and promoter-specific analyses identify sites of differential DNA methylation in normal and transformed human cells. Nat. Genet. 2005, 37, 853-862.

38. Mandel, P. Les acides nucleiques du plasma sanguin chez l'homme. CR Acad. Sci. Paris 1948, 142, 241-243.

39. Zhu, W.; Qin, W.; Hewett, J.E.; Sauter, E.R. Quantitative evaluation of DNA hypermethylation in malignant and benign breast tissue and fluids. Int. J. Cancer 2010, 126, 474-482.

40. Klein, P.M.; Lawrence, J.A. Lavage and nipple aspiration of breast ductal fluids: A source of biomarkers for environmental mutagenesis. Environ. Mol. Mutagen. 2002, 39, 127-133.

41. Cairns, P.; Esteller, M.; Herman, J.G.; Schoenberg, M.; Jeronimo, C.; Sanchez-Cespedes, M.; Chow, N.H.; Grasso, M.; Wu, L.; Westra, W.B.; et al. Molecular detection of prostate cancer in urine by GSTP1 hypermethylation. Clin. Cancer. Res. 2001, 7, 2727-2730.

42. Shi, H.; Wang, M.X.; Caldwell, C.W. CpG islands: Their potential as biomarkers for cancer. Expert Rev. Mol. Diagn. 2007, 7, 519-531.

43. Belinsky, S.A.; Nikula, K.J.; Palmisano, W.A.; Michels, R.; Saccomanno, G.; Gabrielson, E.; Baylin, S.B.; Herman, J.G. Aberrant methylation of p16(INK4a) is an early event in lung cancer and a potential biomarker for early diagnosis. Proc. Natl. Acad. Sci. USA 1998, 95, 11891-11896.

44. Ahrendt, S.A.; Chow, J.T.; Xu, L.H.; Yang, S.C.; Eisenberger, C.F.; Esteller, M.; Herman, J.G.; Wu, L.; Decker, P.A.; Jen, J.; et al. Molecular detection of tumor cells in bronchoalveolar lavage fluid from patients with early stage lung cancer. J. Natl. Cancer Inst. 1999, 91, 332-339. 
45. Silva, J.; Dominguez, G.; Villanueva, M.; Gonzalez, R.; Garcia, J.; Corbacho, C.; Provencio, M.; Espana, P.; Bonilla, F. Aberrant DNA methylation of the p16INK4a gene in plasma DNA of breast cancer patients. Br. J.Cancer 1999, 80, 1262-1264.

46. Cassinotti, E.; Melson, J.; Liggett, T.; Melnikov, A.; Yi, Q.; Replogle, C.; Mobarhan, S.; Boni, L.; Segato, S.; Levenson, V. DNA methylation patterns in blood of patients with colorectal cancer and adenomatous colorectal polyps. Int. J. Cancer 2012, 131, 1153-1157.

47. Radpour, R.; Barekati, Z.; Kohler, C.; Lv, Q.; Burki, N.; Diesch, C.; Bitzer, J.; Zheng, H.; Schmid, S.; Zhong, X.Y. Hypermethylation of tumor suppressor genes involved in critical regulatory pathways for developing a blood-based test in breast cancer. PLoS One 2011, 6, e16080.

48. Lange, C.P.; Campan, M.; Hinoue, T.; Schmitz, R.F.; van der Meulen-de Jong, A.E.; Slingerland, H.; Kok, P.J.; van Dijk, C.M.; Weisenberger, D.J.; Shen, H.; et al. Genome-scale discovery of DNA-methylation biomarkers for blood-based detection of colorectal cancer. PLoS One 2012, 7 , e50266.

49. Shapiro, B.; Chakrabarty, M.; Cohn, E.M.; Leon, S.A. Determination of circulating DNA levels in patients with benign or malignant gastrointestinal disease. Cancer 1983, 51, 2116-2120.

50. Martinez-Galan, J.; Torres, B.; Del Moral, R.; Munoz-Gamez, J.A.; Martin-Oliva, D.; Villalobos, M.; Nunez, M.I.; Luna Jde, D.; Oliver, F.J.; Ruiz de Almodovar, J.M. Quantitative detection of methylated ESR1 and 14-3-3-sigma gene promoters in serum as candidate biomarkers for diagnosis of breast cancer and evaluation of treatment efficacy. Cancer Biol. Ther. 2008, 7, 958-965.

51. Ng, E.K.; Leung, C.P.; Shin, V.Y.; Wong, C.L.; Ma, E.S.; Jin, H.C.; Chu, K.M.; Kwong, A. Quantitative analysis and diagnostic significance of methylated SLC19A3 DNA in the plasma of breast and gastric cancer patients. PLoS One 2011, 6, e22233.

52. Hoque, M.O.; Feng, Q.; Toure, P.; Dem, A.; Critchlow, C.W.; Hawes, S.E.; Wood, T.; Jeronimo, C.; Rosenbaum, E.; Stern, J.; et al. Detection of aberrant methylation of four genes in plasma DNA for the detection of breast cancer. J. Clin. Oncol. 2006, 24, 4262-4269.

53. Chimonidou, M.; Strati, A.; Malamos, N.; Georgoulias, V.; Lianidou, E.S. SOX17 promoter methylation in circulating tumor cells and matched cell-free DNA isolated from plasma of patients with breast cancer. Clin. Chem. 2013, 59, 270-279.

54. Kloten, V.; Becker, B.; Winner, K.; Schrauder, M.G.; Fasching, P.A.; Anzeneder, T.; Veeck, J.; Hartmann, A.; Knuchel, R.; Dahl, E. Promoter hypermethylation of the tumor-suppressor genes ITIH5, DKK3, and RASSF1A as novel biomarkers for blood-based breast cancer screening. Breast Cancer Res. 2013, 15, R4.

55. Ebert, M.P.; Model, F.; Mooney, S.; Hale, K.; Lograsso, J.; Tonnes-Priddy, L.; Hoffmann, J.; Csepregi, A.; Rocken, C.; Molnar, B.; et al. Aristaless-like homeobox-4 gene methylation is a potential marker for colorectal adenocarcinomas. Gastroenterology 2006, 131, 1418-1430.

56. Miotto, E.; Sabbioni, S.; Veronese, A.; Calin, G.A.; Gullini, S.; Liboni, A.; Gramantieri, L.; Bolondi, L.; Ferrazzi, E.; Gafa, R.; et al. Frequent aberrant methylation of the CDH4 gene promoter in human colorectal and gastric cancer. Cancer Res. 2004, 64, 8156-8159.

57. Lofton-Day, C.; Model, F.; Devos, T.; Tetzner, R.; Distler, J.; Schuster, M.; Song, X.; Lesche, R.; Liebenberg, V.; Ebert, M.; et al. DNA methylation biomarkers for blood-based colorectal cancer screening. Clin. Chem. 2008, 54, 414-423. 
58. DeVos, T.; Tetzner, R.; Model, F.; Weiss, G.; Schuster, M.; Distler, J.; Steiger, K.V.; Grutzmann, R.; Pilarsky, C.; Habermann, J.K.; et al. Circulating methylated SEPT9 DNA in plasma is a biomarker for colorectal cancer. Clin. Chem. 2009, 55, 1337-1346.

59. Church, T.R.; Wandell, M.; Lofton-Day, C.; Mongin, S.J.; Burger, M.; Payne, S.R.; Castanos-Velez, E.; Blumenstein, B.A.; Rosch, T.; Osborn, N.; et al. Prospective evaluation of methylated SEPT9 in plasma for detection of asymptomatic colorectal cancer. Gut 2013, doi:10.1136/gutjnl-2012-304149.

60. Kneip, C.; Schmidt, B.; Seegebarth, A.; Weickmann, S.; Fleischhacker, M.; Liebenberg, V.; Field, J.K.; Dietrich, D. SHOX2 DNA methylation is a biomarker for the diagnosis of lung cancer in plasma. J. Thorac. Oncol. 2011, 6, 1632-1638.

61. Zhang, Y.; Wang, R.; Song, H.; Huang, G.; Yi, J.; Zheng, Y.; Wang, J.; Chen, L. Methylation of multiple genes as a candidate biomarker in non-small cell lung cancer. Cancer Lett. 2011, 303, $21-28$.

62. Zhang, Y.; Miao, Y.; Yi, J.; Wang, R.; Chen, L. Frequent epigenetic inactivation of deleted in lung and esophageal cancer 1 gene by promoter methylation in non-small-cell lung cancer. Clin. Lung Cancer 2010, 11, 264-270.

63. Schmiemann, V.; Bocking, A.; Kazimirek, M.; Onofre, A.S.; Gabbert, H.E.; Kappes, R.; Gerharz, C.D.; Grote, H.J. Methylation assay for the diagnosis of lung cancer on bronchial aspirates: A cohort study. Clin. Cancer Res. 2005, 11, 7728-7734.

64. Begum, S.; Brait, M.; Dasgupta, S.; Ostrow, K.L.; Zahurak, M.; Carvalho, A.L.; Califano, J.A.; Goodman, S.N.; Westra, W.H.; Hoque, M.O.; et al. An epigenetic marker panel for detection of lung cancer using cell-free serum DNA. Clin. Cancer Res. 2011, 17, 4494-4503.

65. Hsu, H.S.; Chen, T.P.; Hung, C.H.; Wen, C.K.; Lin, R.K.; Lee, H.C.; Wang, Y.C. Characterization of a multiple epigenetic marker panel for lung cancer detection and risk assessment in plasma. Cancer 2007, 110, 2019-2026.

66. Zheng, Y.; Chen, L.; Li, J.; Yu, B.; Su, L.; Chen, X.; Yu, Y.; Yan, M.; Liu, B.; Zhu, Z. Hypermethylated DNA as potential biomarkers for gastric cancer diagnosis. Clin. Biochem. 2011, 44, 1405-1411.

67. Huang, Z.H.; Hu, Y.; Hua, D.; Wu, Y.Y.; Song, M.X.; Cheng, Z.H. Quantitative analysis of multiple methylated genes in plasma for the diagnosis and prognosis of hepatocellular carcinoma. Exp. Mol. Pathol. 2011, 91, 702-707.

68. Sun, F.K.; Fan, Y.C.; Zhao, J.; Zhang, F.; Gao, S.; Zhao, Z.H.; Sun, Q.; Wang, K. Detection of TFPI2 methylation in the serum of hepatocellular carcinoma patients. Dig. Dis. Sci. 2012, 58, $1010-1015$.

69. Carvalho, A.L.; Jeronimo, C.; Kim, M.M.; Henrique, R.; Zhang, Z.; Hoque, M.O.; Chang, S.; Brait, M.; Nayak, C.S.; Jiang, W.W.; et al. Evaluation of promoter hypermethylation detection in body fluids as a screening/diagnosis tool for head and neck squamous cell carcinoma. Clin. Cancer Res. 2008, 14, 97-107.

70. Melnikov, A.; Scholtens, D.; Godwin, A.; Levenson, V. Differential methylation profile of ovarian cancer in tissues and plasma. J. Mol. Diagn. 2009, 11, 60-65. 
71. Liggett, T.E.; Melnikov, A.; Yi, Q.; Replogle, C.; Hu, W.; Rotmensch, J.; Kamat, A.; Sood, A.K.; Levenson, V. Distinctive DNA methylation patterns of cell-free plasma DNA in women with malignant ovarian tumors. Gynecol. Oncol. 2011, 120, 113-120.

72. Melnikov, A.A.; Scholtens, D.; Talamonti, M.S.; Bentrem, D.J.; Levenson, V.V. Methylation profile of circulating plasma DNA in patients with pancreatic cancer. J. Surg. Oncol. 2009, 99, 119-122.

73. Park, J.K.; Ryu, J.K.; Yoon, W.J.; Lee, S.H.; Lee, G.Y.; Jeong, K.S.; Kim, Y.T.; Yoon, Y.B. The role of quantitative NPTX2 hypermethylation as a novel serum diagnostic marker in pancreatic cancer. Pancreas 2012, 41, 95-101.

74. Jiao, L.; Zhu, J.; Hassan, M.M.; Evans, D.B.; Abbruzzese, J.L.; Li, D. K-ras mutation and p16 and preproenkephalin promoter hypermethylation in plasma DNA of pancreatic cancer patients: In relation to cigarette smoking. Pancreas 2007, 34, 55-62.

75. Hauser, S.; Kogej, M.; Fechner, G.; J, V.O.N.P.; Vorreuther, R.; Lummen, G.; Muller, S.C.; Ellinger, J. Serum DNA hypermethylation in patients with bladder cancer: Results of a prospective multicenter study. Anticancer Res. 2013, 33, 779-784.

76. Ellinger, J.; El Kassem, N.; Heukamp, L.C.; Matthews, S.; Cubukluoz, F.; Kahl, P.; Perabo, F.G.; Muller, S.C.; von Ruecker, A.; Bastian, P.J. Hypermethylation of cell-free serum DNA indicates worse outcome in patients with bladder cancer. J. Urol. 2008, 179, 346-352.

77. Bastian, P.J.; Palapattu, G.S.; Yegnasubramanian, S.; Rogers, C.G.; Lin, X.; Mangold, L.A.; Trock, B.; Eisenberger, M.A.; Partin, A.W.; Nelson, W.G. CpG island hypermethylation profile in the serum of men with clinically localized and hormone refractory metastatic prostate cancer. J. Urol. 2008, 179, 529-534; discussion 534-525.

78. Ellinger, J.; Bastian, P.J.; Jurgan, T.; Biermann, K.; Kahl, P.; Heukamp, L.C.; Wernert, N.; Muller, S.C.; von Ruecker, A. CpG island hypermethylation at multiple gene sites in diagnosis and prognosis of prostate cancer. Urology 2008, 71, 161-167.

79. Leng, S.; Do, K.; Yingling, C.M.; Picchi, M.A.; Wolf, H.J.; Kennedy, T.C.; Feser, W.J.; Baron, A.E.; Franklin, W.A.; Brock, M.V.; et al. Defining a gene promoter methylation signature in sputum for lung cancer risk assessment. Clin. Cancer Res. 2012, 18, 3387-3395.

80. Belinsky, S.A.; Liechty, K.C.; Gentry, F.D.; Wolf, H.J.; Rogers, J.; Vu, K.; Haney, J.; Kennedy, T.C.; Hirsch, F.R.; Miller, Y.; et al. Promoter hypermethylation of multiple genes in sputum precedes lung cancer incidence in a high-risk cohort. Cancer Res. 2006, 66, 3338-3344.

81. Carvalho, A.L.; Henrique, R.; Jeronimo, C.; Nayak, C.S.; Reddy, A.N.; Hoque, M.O.; Chang, S.; Brait, M.; Jiang, W.W.; Kim, M.M.; et al. Detection of promoter hypermethylation in salivary rinses as a biomarker for head and neck squamous cell carcinoma surveillance. Clin. Cancer Res. 2011, 17, 4782-4789.

82. Payne, S.R.; Serth, J.; Schostak, M.; Kamradt, J.; Strauss, A.; Thelen, P.; Model, F.; Day, J.K.; Liebenberg, V.; Morotti, A.; et al. DNA methylation biomarkers of prostate cancer: Confirmation of candidates and evidence urine is the most sensitive body fluid for non-invasive detection. Prostate 2009, 69, 1257-1269.

83. Roupret, M.; Hupertan, V.; Yates, D.R.; Catto, J.W.; Rehman, I.; Meuth, M.; Ricci, S.; Lacave, R.; Cancel-Tassin, G.; de la Taille, A.; et al. Molecular detection of localized prostate cancer using quantitative methylation-specific PCR on urinary cells obtained following prostate massage. Clin. Cancer Res. 2007, 13, 1720-1725. 
84. Costa, V.L.; Henrique, R.; Danielsen, S.A.; Eknaes, M.; Patricio, P.; Morais, A.; Oliveira, J.; Lothe, R.A.; Teixeira, M.R.; Lind, G.E.; et al. TCF21 and PCDH17 methylation: An innovative panel of biomarkers for a simultaneous detection of urological cancers. Epigenetics 2011, 6, 1120-1130.

85. Glockner, S.C.; Dhir, M.; Yi, J.M.; McGarvey, K.E.; Van Neste, L.; Louwagie, J.; Chan, T.A.; Kleeberger, W.; de Bruine, A.P.; Smits, K.M.; et al. Methylation of TFPI2 in stool DNA: A potential novel biomarker for the detection of colorectal cancer. Cancer Res. 2009, 69, 4691-4699.

86. Hellebrekers, D.M.; Lentjes, M.H.; van den Bosch, S.M.; Melotte, V.; Wouters, K.A.; Daenen, K.L.; Smits, K.M.; Akiyama, Y.; Yuasa, Y.; Sanduleanu, S.; et al. GATA4 and GATA5 are potential tumor suppressors and biomarkers in colorectal cancer. Clin. Cancer Res. 2009, 15, 3990-3997.

87. Melotte, V.; Lentjes, M.H.; van den Bosch, S.M.; Hellebrekers, D.M.; de Hoon, J.P.; Wouters, K.A.; Daenen, K.L.; Partouns-Hendriks, I.E.; Stessels, F.; Louwagie, J.; et al. N-Myc downstream-regulated gene 4 (NDRG4): A candidate tumor suppressor gene and potential biomarker for colorectal cancer. J. Natl. Cancer Inst. 2009, 101, 916-927.

88. Chen, W.D.; Han, Z.J.; Skoletsky, J.; Olson, J.; Sah, J.; Myeroff, L.; Platzer, P.; Lu, S.; Dawson, D.; Willis, J.; et al. Detection in fecal DNA of colon cancer-specific methylation of the nonexpressed vimentin gene. J. Natl. Cancer Inst. 2005, 97, 1124-1132.

89. Costa, V.L.; Henrique, R.; Danielsen, S.A.; Duarte-Pereira, S.; Eknaes, M.; Skotheim, R.I.; Rodrigues, A.; Magalhaes, J.S.; Oliveira, J.; Lothe, R.A.; et al. Three epigenetic biomarkers, GDF15, TMEFF2, and VIM, accurately predict bladder cancer from DNA-based analyses of urine samples. Clin. Cancer Res. 2010, 16, 5842-5851.

90. Zhao, Y.; Guo, S.; Sun, J.; Huang, Z.; Zhu, T.; Zhang, H.; Gu, J.; He, Y.; Wang, W.; Ma, K.; et al. Methylcap-seq reveals novel DNA methylation markers for the diagnosis and recurrence prediction of bladder cancer in a Chinese population. PLoS One 2012, 7, e35175.

91. Reinert, T.; Modin, C.; Castano, F.M.; Lamy, P.; Wojdacz, T.K.; Hansen, L.L.; Wiuf, C.; Borre, M.; Dyrskjot, L.; Orntoft, T.F. Comprehensive genome methylation analysis in bladder cancer: Identification and validation of novel methylated genes and application of these as urinary tumor markers. Clin. Cancer Res. 2011, 17, 5582-5592.

92. Yu, J.; Zhu, T.; Wang, Z.; Zhang, H.; Qian, Z.; Xu, H.; Gao, B.; Wang, W.; Gu, L.; Meng, J.; et al. A novel set of DNA methylation markers in urine sediments for sensitive/specific detection of bladder cancer. Clin. Cancer Res. 2007, 13, 7296-7304.

93. Skvortsova, T.E.; Rykova, E.Y.; Tamkovich, S.N.; Bryzgunova, O.E.; Starikov, A.V.; Kuznetsova, N.P.; Vlassov, V.V.; Laktionov, P.P. Cell-free and cell-bound circulating DNA in breast tumours: DNA quantification and analysis of tumour-related gene methylation. $\mathrm{Br} . \mathrm{J}$. Cancer 2006, 94, 1492-1495.

94. Hoque, M.O.; Begum, S.; Topaloglu, O.; Jeronimo, C.; Mambo, E.; Westra, W.H.; Califano, J.A.; Sidransky, D. Quantitative detection of promoter hypermethylation of multiple genes in the tumor, urine, and serum DNA of patients with renal cancer. Cancer Res. 2004, 64, 5511-5517.

95. Goessl, C.; Krause, H.; Muller, M.; Heicappell, R.; Schrader, M.; Sachsinger, J.; Miller, K. Fluorescent methylation-specific polymerase chain reaction for DNA-based detection of prostate cancer in bodily fluids. Cancer Res. 2000, 60, 5941-5945. 
96. Goessl, C.; Muller, M.; Heicappell, R.; Krause, H.; Straub, B.; Schrader, M.; Miller, K. DNA-based detection of prostate cancer in urine after prostatic massage. Urology 2001, 58, 335-338.

97. Jeronimo, C.; Usadel, H.; Henrique, R.; Silva, C.; Oliveira, J.; Lopes, C.; Sidransky, D. Quantitative GSTP1 hypermethylation in bodily fluids of patients with prostate cancer. Urology 2002, 60, 1131-1135.

98. Kagan, J.; Srivastava, S.; Barker, P.E.; Belinsky, S.A.; Cairns, P. Towards clinical application of methylated DNA sequences as cancer biomarkers: A joint NCI's EDRN and NIST workshop on standards, methods, assays, reagents and tools. Cancer Res. 2007, 67, 4545-4549.

99. Lagos-Quintana, M.; Rauhut, R.; Lendeckel, W.; Tuschl, T. Identification of novel genes coding for small expressed RNAs. Science 2001, 294, 853-858.

100. Siomi, H.; Siomi, M.C. Posttranscriptional regulation of microRNA biogenesis in animals. Mol. Cell 2010, 38, 323-332.

101. Lee, R.C.; Feinbaum, R.L.; Ambros, V. The C. elegans heterochronic gene lin-4 encodes small rnas with antisense complementarity to lin-14. Cell 1993, 75, 843-854.

102. Filipowicz, W.; Bhattacharyya, S.N.; Sonenberg, N. Mechanisms of post-transcriptional regulation by microRNAs: Are the answers in sight? Nat. Rev. Genet. 2008, 9, 102-114.

103. Plasterk, R.H. Micro rnas in animal development. Cell 2006, 124, 877-881.

104. Bartel, D.P. MicroRNAs: Genomics, biogenesis, mechanism, and function. Cell 2004, 116, 281-297.

105. He, L.; Hannon, G.J. MicroRNAs: Small rnas with a big role in gene regulation. Nat. Rev. Genet. 2004, 5, 522-531.

106. Esquela-Kerscher, A.; Slack, F.J. Oncomirs - microRNAs with a role in cancer. Nat. Rev. Cancer 2006, 6, 259-269.

107. Calin, G.A.; Croce, C.M. MicroRNA signatures in human cancers. Nat. Rev. Cancer 2006, 6, $857-866$.

108. Yu, S.L.; Chen, H.Y.; Chang, G.C.; Chen, C.Y.; Chen, H.W.; Singh, S.; Cheng, C.L.; Yu, C.J.; Lee, Y.C.; Chen, H.S.; et al. MicroRNA signature predicts survival and relapse in lung cancer. Cancer Cell 2008, 13, 48-57.

109. Liu, N.; Chen, N.Y.; Cui, R.X.; Li, W.F.; Li, Y.; Wei, R.R.; Zhang, M.Y.; Sun, Y.; Huang, B.J.; Chen, M.; et al. Prognostic value of a microRNA signature in nasopharyngeal carcinoma: A microRNA expression analysis. Lancet Oncol. 2012, 13, 633-641.

110. Rotkrua, P.; Shimada, S.; Mogushi, K.; Akiyama, Y.; Tanaka, H.; Yuasa, Y. Circulating microRNAs as biomarkers for early detection of diffuse-type gastric cancer using a mouse model. Br. J. Cancer 2013, 108, 932-940.

111. Cho, W.C. MicroRNAs: Potential biomarkers for cancer diagnosis, prognosis and targets for therapy. Int. J. Biochem. Cell Biol. 2010, 42, 1273-1281.

112. Chen, C.; Ridzon, D.A.; Broomer, A.J.; Zhou, Z.; Lee, D.H.; Nguyen, J.T.; Barbisin, M.; $\mathrm{Xu}$, N.L.; Mahuvakar, V.R.; Andersen, M.R.; et al. Real-time quantification of microRNAs by stem-loop RT-PCR. Nucleic Acids Res. 2005, 33, e179.

113. Mestdagh, P.; Feys, T.; Bernard, N.; Guenther, S.; Chen, C.; Speleman, F.; Vandesompele, J. High-throughput stem-loop RT-qPCR mirna expression profiling using minute amounts of input RNA. Nucleic Acids Res. 2008, 36, e143. 
114. Kroh, E.M.; Parkin, R.K.; Mitchell, P.S.; Tewari, M. Analysis of circulating microRNA biomarkers in plasma and serum using quantitative reverse transcription-PCR (qRT-PCR). Methods 2010, 50, 298-301.

115. Baker, M. MicroRNA profiling: Separating signal from noise. Nat Methods 2010, 7, 687-692.

116. Mestdagh, P.; Van Vlierberghe, P.; De Weer, A.; Muth, D.; Westermann, F.; Speleman, F.; Vandesompele, J. A novel and universal method for microRNA RT-qPCR data normalization. Genome Biol. 2009, 10, R64.

117. Gallo, A.; Tandon, M.; Alevizos, I.; Illei, G.G. The majority of microRNAs detectable in serum and saliva is concentrated in exosomes. PLoS One 2012, 7, e30679.

118. Pritchard, C.C.; Kroh, E.; Wood, B.; Arroyo, J.D.; Dougherty, K.J.; Miyaji, M.M.; Tait, J.F.; Tewari, M. Blood cell origin of circulating microRNAs: A cautionary note for cancer biomarker studies. Cancer Prev. Res. (Phila) 2012, 5, 492-497.

119. McDonald, J.S.; Milosevic, D.; Reddi, H.V.; Grebe, S.K.; Algeciras-Schimnich, A. Analysis of circulating microRNA: Preanalytical and analytical challenges. Clin. Chem. 2011, 57, 833-840.

120. Kirschner, M.B.; Kao, S.C.; Edelman, J.J.; Armstrong, N.J.; Vallely, M.P.; van Zandwijk, N.; Reid, G. Haemolysis during sample preparation alters microRNA content of plasma. PLoS One 2011, 6, e24145.

121. Chen, X.; Ba, Y.; Ma, L.; Cai, X.; Yin, Y.; Wang, K.; Guo, J.; Zhang, Y.; Chen, J.; Guo, X.; et al. Characterization of microRNAs in serum: A novel class of biomarkers for diagnosis of cancer and other diseases. Cell Res. 2008, 18, 997-1006.

122. Keller, A.; Leidinger, P.; Gislefoss, R.; Haugen, A.; Langseth, H.; Staehler, P.; Lenhof, H.P.; Meese, E. Stable serum mirna profiles as potential tool for non-invasive lung cancer diagnosis. RNA Biol. 2011, 8, 506-516.

123. Lawrie, C.H.; Gal, S.; Dunlop, H.M.; Pushkaran, B.; Liggins, A.P.; Pulford, K.; Banham, A.H.; Pezzella, F.; Boultwood, J.; Wainscoat, J.S.; et al. Detection of elevated levels of tumour-associated microRNAs in serum of patients with diffuse large B-cell lymphoma. Br. J. Haematol. 2008, 141, 672-675.

124. Mitchell, P.S.; Parkin, R.K.; Kroh, E.M.; Fritz, B.R.; Wyman, S.K.; Pogosova-Agadjanyan, E.L.; Peterson, A.; Noteboom, J.; O'Briant, K.C.; Allen, A.; et al. Circulating microRNAs as stable blood-based markers for cancer detection. Proc. Natl. Acad. Sci. USA 2008, 105, 10513-10518.

125. Gonzales, J.C.; Fink, L.M.; Goodman, O.B. Jr.; Symanowski, J.T.; Vogelzang, N.J.; Ward, D.C. Comparison of circulating microRNA 141 to circulating tumor cells, lactate dehydrogenase, and prostate-specific antigen for determining treatment response in patients with metastatic prostate cancer. Clin. Genitourin. Cancer 2011, 9, 39-45.

126. Zhu, W.; Qin, W.; Atasoy, U.; Sauter, E.R. Circulating microRNAs in breast cancer and healthy subjects. BMC Res. Notes 2009, 2, 89.

127. Heneghan, H.M.; Miller, N.; Lowery, A.J.; Sweeney, K.J.; Newell, J.; Kerin, M.J. Circulating microRNAs as novel minimally invasive biomarkers for breast cancer. Ann. Surg. 2010, 251, 499-505.

128. Roth, C.; Rack, B.; Muller, V.; Janni, W.; Pantel, K.; Schwarzenbach, H. Circulating microRNAs as blood-based markers for patients with primary and metastatic breast cancer. Breast Cancer Res. 2010, 12, R90. 
129. Heneghan, H.M.; Miller, N.; Kelly, R.; Newell, J.; Kerin, M.J. Systemic miRNA-195 differentiates breast cancer from other malignancies and is a potential biomarker for detecting noninvasive and early stage disease. Oncologist 2010, 15, 673-682.

130. Wu, Q.; Lu, Z.; Li, H.; Lu, J.; Guo, L.; Ge, Q. Next-generation sequencing of microRNAs for breast cancer detection. J. Biomed. Biotechnol. 2011, $2011,597145$.

131. Hu, Z.; Dong, J.; Wang, L.E.; Ma, H.; Liu, J.; Zhao, Y.; Tang, J.; Chen, X.; Dai, J.; Wei, Q.; et al. Serum microRNA profiling and breast cancer risk: The use of miR-484/191 as endogenous controls. Carcinogenesis 2012, 33, 828-834.

132. Ng, E.K.; Chong, W.W.; Jin, H.; Lam, E.K.; Shin, V.Y.; Yu, J.; Poon, T.C.; Ng, S.S.; Sung, J.J. Differential expression of microRNAs in plasma of patients with colorectal cancer: A potential marker for colorectal cancer screening. Gut 2009, 58, 1375-1381.

133. Huang, Z.; Huang, D.; Ni, S.; Peng, Z.; Sheng, W.; Du, X. Plasma microRNAs are promising novel biomarkers for early detection of colorectal cancer. Int. J. Cancer 2010, 127, 118-126.

134. Pu, X.X.; Huang, G.L.; Guo, H.Q.; Guo, C.C.; Li, H.; Ye, S.; Ling, S.; Jiang, L.; Tian, Y.; Lin, T.Y. Circulating miR-221 directly amplified from plasma is a potential diagnostic and prognostic marker of colorectal cancer and is correlated with p53 expression. J. Gastroenterol. Hepatol. 2010, 25, 1674-1680.

135. Wang, L.G.; Gu, J. Serum microRNA-29a is a promising novel marker for early detection of colorectal liver metastasis. Cancer Epidemiol. 2012, 36, e61-e67.

136. Cheng, H.; Zhang, L.; Cogdell, D.E.; Zheng, H.; Schetter, A.J.; Nykter, M.; Harris, C.C.; Chen, K.; Hamilton, S.R.; Zhang, W. Circulating plasma miR-141 is a novel biomarker for metastatic colon cancer and predicts poor prognosis. PLoS One 2011, 6, e17745.

137. Nugent, M.; Miller, N.; Kerin, M.J. Circulating miR-34a levels are reduced in colorectal cancer. J. Surg. Oncol. 2012, 106, 947-952.

138. Tsujiura, M.; Ichikawa, D.; Komatsu, S.; Shiozaki, A.; Takeshita, H.; Kosuga, T.; Konishi, H.; Morimura, R.; Deguchi, K.; Fujiwara, H.; et al. Circulating microRNAs in plasma of patients with gastric cancers. Br. J. Cancer 2010, 102, 1174-1179.

139. Zhou, H.; Guo, J.M.; Lou, Y.R.; Zhang, X.J.; Zhong, F.D.; Jiang, Z.; Cheng, J.; Xiao, B.X. Detection of circulating tumor cells in peripheral blood from patients with gastric cancer using microRNA as a marker. J. Mol. Med. (Berl) 2010, 88, 709-717.

140. Liu, H.; Zhu, L.; Liu, B.; Yang, L.; Meng, X.; Zhang, W.; Ma, Y.; Xiao, H. Genome-wide microRNA profiles identify miR-378 as a serum biomarker for early detection of gastric cancer. Cancer Lett. 2012, 316, 196-203.

141. Tsai, K.W.; Liao, Y.L.; Wu, C.W.; Hu, L.Y.; Li, S.C.; Chan, W.C.; Ho, M.R.; Lai, C.H.; Kao, H.W.; Fang, W.L.; et al. Aberrant expression of miR-196a in gastric cancers and correlation with recurrence. Genes Chromosom. Cancer 2012, 51, 394-401.

142. Valladares-Ayerbes, M.; Reboredo, M.; Medina-Villaamil, V.; Iglesias-Diaz, P.; Lorenzo-Patino, M.J.; Haz, M.; Santamarina, I.; Blanco, M.; Fernandez-Tajes, J.; Quindos, M .; et al. Circulating miR-200c as a diagnostic and prognostic biomarker for gastric cancer. J. Transl. Med. 2012, 10, 186.

143. Wang, M.; Gu, H.; Wang, S.; Qian, H.; Zhu, W.; Zhang, L.; Zhao, C.; Tao, Y.; Xu, W. Circulating miR-17-5p and miR-20a: Molecular markers for gastric cancer. Mol. Med. Rep. 2012, $5,1514-1520$. 
144. Zheng, Y.; Cui, L.; Sun, W.; Zhou, H.; Yuan, X.; Huo, M.; Chen, J.; Lou, Y.; Guo, J. MicroRNA-21 is a new marker of circulating tumor cells in gastric cancer patients. Cancer Biomark 2011, 10, 71-77.

145. Gorur, A.; Balci Fidanci, S.; Dogruer Unal, N.; Ayaz, L.; Akbayir, S.; Yildirim Yaroglu, H.; Dirlik, M.; Serin, M.S.; Tamer, L. Determination of plasma microRNA for early detection of gastric cancer. Mol. Biol. Rep. 2012, 40, 2091-1096.

146. Rabinowits, G.; Gercel-Taylor, C.; Day, J.M.; Taylor, D.D.; Kloecker, G.H. Exosomal microRNA: A diagnostic marker for lung cancer. Clin. Lung Cancer 2009, 10, 42-46.

147. Hu, Z.; Chen, X.; Zhao, Y.; Tian, T.; Jin, G.; Shu, Y.; Chen, Y.; Xu, L.; Zen, K.; Zhang, C.; et al. Serum microRNA signatures identified in a genome-wide serum microRNA expression profiling predict survival of non-small-cell lung cancer. J. Clin. Oncol. 2010, 28, 1721-1726.

148. Heegaard, N.H.; Schetter, A.J.; Welsh, J.A.; Yoneda, M.; Bowman, E.D.; Harris, C.C. Circulating micro-RNA expression profiles in early stage nonsmall cell lung cancer. Int. J. Cancer 2012, 130, 1378-1386.

149. Le, H.B.; Zhu, W.Y.; Chen, D.D.; He, J.Y.; Huang, Y.Y.; Liu, X.G.; Zhang, Y.K. Evaluation of dynamic change of serum miR-21 and miR-24 in pre- and post-operative lung carcinoma patients. Med. Oncol. 2012, 29, 3190-3197.

150. Wang, J.; Chen, J.; Chang, P.; LeBlanc, A.; Li, D.; Abbruzzesse, J.L.; Frazier, M.L.; Killary, A.M.; Sen, S. MicroRNAs in plasma of pancreatic ductal adenocarcinoma patients as novel blood-based biomarkers of disease. Cancer Prev. Res. (Phila) 2009, 2, 807-813.

151. Ho, A.S.; Huang, X.; Cao, H.; Christman-Skieller, C.; Bennewith, K.; Le, Q.T.; Koong, A.C. Circulating miR-210 as a novel hypoxia marker in pancreatic cancer. Transl. Oncol. 2010, 3, 109-113.

152. Li, A.; Omura, N.; Hong, S.M.; Vincent, A.; Walter, K.; Griffith, M.; Borges, M.; Goggins, M. Pancreatic cancers epigenetically silence SIP1 and hypomethylate and overexpress miR-200a/200b in association with elevated circulating miR-200a and miR-200b levels. Cancer Res. 2010, 70, 5226-5237.

153. Morimura, R.; Komatsu, S.; Ichikawa, D.; Takeshita, H.; Tsujiura, M.; Nagata, H.; Konishi, H.; Shiozaki, A.; Ikoma, H.; Okamoto, K .; et al. Novel diagnostic value of circulating miR-18a in plasma of patients with pancreatic cancer. Br. J. Cancer 2011, 105, 1733-1740.

154. Yamamoto, Y.; Kosaka, N.; Tanaka, M.; Koizumi, F.; Kanai, Y.; Mizutani, T.; Murakami, Y.; Kuroda, M.; Miyajima, A.; Kato, T ; et al. MicroRNA-500 as a potential diagnostic marker for hepatocellular carcinoma. Biomarkers 2009, 14, 529-538.

155. Li, L.M.; Hu, Z.B.; Zhou, Z.X.; Chen, X.; Liu, F.Y.; Zhang, J.F.; Shen, H.B.; Zhang, C.Y.; Zen, K. Serum microRNA profiles serve as novel biomarkers for HBV infection and diagnosis of HBV-positive hepatocarcinoma. Cancer Res. 2010, 70, 9798-9807.

156. Qi, P.; Cheng, S.Q.; Wang, H.; Li, N.; Chen, Y.F.; Gao, C.F. Serum microRNAs as biomarkers for hepatocellular carcinoma in Chinese patients with chronic hepatitis B virus infection. PLoS One 2011, 6, e28486.

157. Liu, A.M.; Yao, T.J.; Wang, W.; Wong, K.F.; Lee, N.P.; Fan, S.T.; Poon, R.T.; Gao, C.; Luk, J.M. Circulating miR-15b and miR-130b in serum as potential markers for detecting hepatocellular carcinoma: A retrospective cohort study. BMJ Open 2012, 2, e000825. 
158. Sukata, T.; Sumida, K.; Kushida, M.; Ogata, K.; Miyata, K.; Yabushita, S.; Uwagawa, S. Circulating microRNAs, possible indicators of progress of rat hepatocarcinogenesis from early stages. Toxicol. Lett. 2011, 200, 46-52.

159. Xu, J.; Wu, C.; Che, X.; Wang, L.; Yu, D.; Zhang, T.; Huang, L.; Li, H.; Tan, W.; Wang, C.; et al. Circulating microRNAs, miR-21, miR-122, and miR-223, in patients with hepatocellular carcinoma or chronic hepatitis. Mol. Carcinog. 2011, 50, 136-142.

160. Hsu, C.M.; Lin, P.M.; Wang, Y.M.; Chen, Z.J.; Lin, S.F.; Yang, M.Y. Circulating miRNA is a novel marker for head and neck squamous cell carcinoma. Tumour. Biol. 2012, 33, 1933-1942.

161. Wong, T.S.; Ho, W.K.; Chan, J.Y.; Ng, R.W.; Wei, W.I. Mature miR-184 and squamous cell carcinoma of the tongue. Sci. World J. 2009, 9, 130-132.

162. Liu, C.J.; Kao, S.Y.; Tu, H.F.; Tsai, M.M.; Chang, K.W.; Lin, S.C. Increase of microRNA miR-31 level in plasma could be a potential marker of oral cancer. Oral Dis. 2010, 16, 360-364.

163. Lin, S.C.; Liu, C.J.; Lin, J.A.; Chiang, W.F.; Hung, P.S.; Chang, K.W. MiR-24 up-regulation in oral carcinoma: Positive association from clinical and in vitro analysis. Oral Oncol. 2010, 46, 204-208.

164. Hussein, F.K.; Nizar, B.; Mehdi, N.; Philippe, L.; Mohammad, F.K.; Rabih, B.; Eva, H.; Ahmad, D.; Nader, H.; Rim, E.D.; et al. Circulating miR-150 and miR-342 in plasma are novel potential biomarkers for acute myeloid leukemia. J. Transl. Med. 2013, 11, 31.

165. Jones, C.I.; Zabolotskaya, M.V.; King, A.J.; Stewart, H.J.; Horne, G.A.; Chevassut, T.J.; Newbury, S.F. Identification of circulating microRNAs as diagnostic biomarkers for use in multiple myeloma. Br. J. Cancer 2012, 107, 1987-1996.

166. Lodes, M.J.; Caraballo, M.; Suciu, D.; Munro, S.; Kumar, A.; Anderson, B. Detection of cancer with serum miRNAs on an oligonucleotide microarray. PLoS One 2009, 4, e6229.

167. Zheng, C.; Yinghao, S.; Li, J. MiR-221 expression affects invasion potential of human prostate carcinoma cell lines by targeting DVL2. Med. Oncol. 2012, 29, 815-822.

168. Yaman Agaoglu, F.; Kovancilar, M.; Dizdar, Y.; Darendeliler, E.; Holdenrieder, S.; Dalay, N.; Gezer, U. Investigation of miR-21, miR-141, and miR-221 in blood circulation of patients with prostate cancer. Tumour. Biol. 2011, 32, 583-588.

169. Moltzahn, F.; Olshen, A.B.; Baehner, L.; Peek, A.; Fong, L.; Stoppler, H.; Simko, J.; Hilton, J.F.; Carroll, P.; Blelloch, R. Microfluidic-based multiplex qRT-PCR identifies diagnostic and prognostic microRNA signatures in the sera of prostate cancer patients. Cancer Res. 2011, 71, 550-560.

170. Resnick, K.E.; Alder, H.; Hagan, J.P.; Richardson, D.L.; Croce, C.M.; Cohn, D.E. The detection of differentially expressed microRNAs from the serum of ovarian cancer patients using a novel real-time PCR platform. Gynecol. Oncol. 2009, 112, 55-59.

171. Taylor, D.D.; Gercel-Taylor, C. MicroRNA signatures of tumor-derived exosomes as diagnostic biomarkers of ovarian cancer. Gynecol. Oncol. 2008, 110, 13-21.

172. Kan, C.W.; Hahn, M.A.; Gard, G.B.; Maidens, J.; Huh, J.Y.; Marsh, D.J.; Howell, V.M. Elevated levels of circulating microRNA-200 family members correlate with serous epithelial ovarian cancer. BMC Cancer 2012, 12, 627.

173. Skog, J.; Wurdinger, T.; van Rijn, S.; Meijer, D.H.; Gainche, L.; Sena-Esteves, M.; Curry, W.T. Jr.; Carter, B.S.; Krichevsky, A.M.; Breakefield, X.O. Glioblastoma microvesicles transport RNA and proteins that promote tumour growth and provide diagnostic biomarkers. Nat. Cell Biol. 2008, 10, 1470-1476. 
174. Weber, J.A.; Baxter, D.H.; Zhang, S.; Huang, D.Y.; Huang, K.H.; Lee, M.J.; Galas, D.J.; Wang, K. The microRNA spectrum in 12 body fluids. Clin. Chem. 2010, 56, 1733-1741.

175. Ge, Y.; Xiao, L.; Chen, X.; Peng, Y.; Sun, L.; Liu, F. Micrornas in peritoneal dialysis effluent are promising biomarkers for peritoneal fibrosis in peritoneal dialysis patients. Med. Hypotheses 2012, 78, 155-156.

176. Yamada, Y.; Enokida, H.; Kojima, S.; Kawakami, K.; Chiyomaru, T.; Tatarano, S.; Yoshino, H.; Kawahara, K.; Nishiyama, K.; Seki, N .; et al. MiR-96 and miR-183 detection in urine serve as potential tumor markers of urothelial carcinoma: Correlation with stage and grade, and comparison with urinary cytology. Cancer Sci. 2011, 102, 522-529.

177. Xing, L.; Todd, N.W.; Yu, L.; Fang, H.; Jiang, F. Early detection of squamous cell lung cancer in sputum by a panel of microrna markers. Mod. Pathol. 2010, 23, 1157-1164.

178. Park, N.J.; Zhou, H.; Elashoff, D.; Henson, B.S.; Kastratovic, D.A.; Abemayor, E.; Wong, D.T. Salivary microRNA: Discovery, characterization, and clinical utility for oral cancer detection. Clin. Cancer Res. 2009, 15, 5473-5477.

179. Han, H.S.; Yun, J.; Lim, S.N.; Han, J.H.; Lee, K.H.; Kim, S.T.; Kang, M.H.; Son, S.M.; Lee, Y.M.; Choi, S.Y .; et al. Downregulation of cell-free miR-198 as a diagnostic biomarker for lung adenocarcinoma-associated malignant pleural effusion. Int. J. Cancer 2013, doi:10.1002/ijc.28054.

180. Cho, W.C. Circulating microRNAs as minimally invasive biomarkers for cancer theragnosis and prognosis. Front. Genet. 2011, $2,7$.

181. Meyer, S.U.; Pfaffl, M.W.; Ulbrich, S.E. Normalization strategies for microRNA profiling experiments: A "normal" way to a hidden layer of complexity? Biotechnol. Lett. 2010, 32, 1777-1788.

182. Sturgeon, C.M.; Hoffman, B.R.; Chan, D.W.; Ch'ng, S.L.; Hammond, E.; Hayes, D.F.; Liotta, L.A.; Petricoin, E.F.; Schmitt, M.; Semmes, O.J. National academy of clinical biochemistry laboratory medicine practice guidelines for use of tumor markers in clinical practice: Quality requirements. Clin. Chem. 2008, 54, e1-e10.

(C) 2013 by the authors; licensee MDPI, Basel, Switzerland. This article is an open access article distributed under the terms and conditions of the Creative Commons Attribution license (http://creativecommons.org/licenses/by/3.0/). 